\title{
Karyotypes of three species of the genus Trissolcus Ashmead, 1893 (Hymenoptera: Scelionidae)
}

\author{
Кариотипы трех видов рода Trissolcus Ashmead, 1893 \\ (Hymenoptera: Scelionidae)
}

\author{
V.E. Gokhman ${ }^{1}$, A.V. Timokhov ${ }^{2}$ \\ B.E. Гохман ${ }^{1}$, A.B. Тимохов $^{2}$
}

\footnotetext{
${ }^{1}$ Botanical Garden, Moscow State University, Moscow 119234, Russia. E-mail: vegokhman@hotmail.com

2 Department of Entomology, Moscow State University, Moscow 119234, Russia. E-mail: atimokhov@mail.ru

${ }^{1}$ Ботанический сад Московского государственного университета, Москва 119234, Россия.

2 Кафедра энтомологии Московского государственного университета, Москва 119234, Россия.
}

KEY WORDS. Telenominae, karyotype, chromosome morphometrics.

КЛЮЧЕВЫЕ СЛОВА. Telenominae, кариотип, морфометрия хромосом.

ABSTRACT. Karyotypes of three species of the genus Trissolcus Ashmead, 1893, namely, T. kozlovi Rjachovsky, 1975, T. rufiventris (Mayr, 1907) and T. semistriatus (Nees von Esenbeck, 1834), were studied for the first time. Although all examined members of the genus appeared to have $2 \mathrm{n}=20$, chromosome morphometrics revealed substantial differences between karyotypes of certain species.

РЕЗЮМЕ. Впервые изучены кариотипы трёх видов рода Trissolcus Ashmead, 1893: T. kozlovi Rjachovsky, 1975, T. rufiventris (Mayr, 1907) и $T$. semistriatus (Nees von Esenbeck, 1834). Хотя у всех исследованных представителей рода обнаружено 2 n $=20$, морфометрия хромосом выявила существенные различия между кариотипами некоторых видов.

\section{Introduction}

Parasitoid Hymenoptera is one of the most speciesrich, taxonomically complicated and economically important insect groups [Godfray, 1994; Quicke, 1997], with its estimated species number in the world fauna exceeding one million [Bebber et al., 2014; Forbes et al., 2018]. Despite rapid accumulation of karyotypic data, they are still available for just about 500 parasitoid species [Gokhman, 2009]. The superfamily Platygastroidea currently comprises more than 6000 described species [Platygastroidea, 2019]. This group is traditionally subdivided into two separate families, Platygastridae and Scelionidae; however, they are often lumped into Platygastridae s.1. (see discussion in [Popovici et al., 2017]).
Among Scelionidae, karyotypes of just three members of the subfamily Telenominae were previously studied [Dreyfus, Breuer, 1944; Gokhman, 2009; Fusu et al., 2013]. Although all examined species appeared to have the same haploid chromosome number, $\mathrm{n}=10$, the known data on chromosome morphology suggest that at least some members of the family can differ in this respect [Dreyfus, Breuer, 1944; Fusu et al., 2013]. We have recently studied karyotypes of three species of Telenominae that belong to the genus Trissolcus Ashmead, 1893. The results of this work are given below.

\section{Material and methods}

\section{Origin of parasitoids}

Parasitic wasps used in the present study were reared from egg clutches of true bugs (Hemiptera: Pentatomidae) or collected by sweeping in their natural habitats in a few regions of European Russia, namely, in the Moscow and Volgograd Provinces as well as in the Republic of Kalmykia, in 2014-2016 (Table 1). Specimens of Trissolcus kozlovi Rjachovsky, 1975 were reared from parasitized eggs of the green shield bug, Palomena prasina (Linnaeus, 1761), and then transferred in the lab to another host, Graphosoma lineatum Linnaeus, 1758. Individuals of T. rufiventris (Mayr, 1907) were collected alive and then temporarily cultivated in the lab on $G$. lineatum. Egg clutches of the same host were deposited in the field to collect $T$. semistriatus (Nees von Esenbeck, 1834). Fresh egg clutches of G. lineatum were given to the fertilized parasitoid females for oviposition. To obtain wasp prepupae, parasitized host eggs were incubated in lab conditions for a few days.

How to cite this article: Gokhman V.E., Timokhov A.V. 2019. Karyotypes of three species of the genus Trissolcus Ashmead, 1893 (Hymenoptera: Scelionidae) // Russian Entomol. J. Vol.28. No.1. P.69-71. doi: 10.15298/rusentj.28.1.11 
Table 1. Species of the genus Trissolcus used in the present study. Таблица 1. Виды рода Trissolcus, использованные в настоящей работе.

\begin{tabular}{|l|l|c|c}
\hline \multicolumn{1}{|c|}{ Species } & \multicolumn{1}{|c|}{ Locality } & $\begin{array}{c}\text { No. studied } \\
\text { No. studied } \\
\text { specimens }\end{array}$ & $\begin{array}{c}\text { Naploid) } \text { and } \\
\text { diploid metaphase } \\
\text { plates }\end{array}$ \\
\hline $\begin{array}{l}\text { T. kozlovi } \\
\text { Rjachovsky, 1975 }\end{array}$ & $\begin{array}{l}\text { Prioksko-Terrasny Natural Reserve, about 100 } \\
\text { km S Moscow }\end{array}$ & 2 & 12 \\
\hline $\begin{array}{l}\text { T. rufiventris } \\
\text { (Mayr, 1907) }\end{array}$ & NW Mikhailovka, about 220 km NW Volgograd & 3 & $(7) 2$ \\
\cline { 2 - 4 } & S Frolovo, about 110 km NW Volgograd & 1 & 1 \\
\hline \multirow{2}{*}{$\begin{array}{l}\text { T. semistriatus } \\
\text { (Nees von Esenbeck, 1834) }\end{array}$} & Razdory, about 20 km W Moscow & 2 & 7 \\
\cline { 2 - 4 } & NW Dubovka, about 50 km N Volgograd & 4 & 17 \\
\cline { 2 - 4 } & E Malye Derbety, about 190 km NE Elista & 3 & 11 \\
\hline
\end{tabular}

Species used in the present study were identified by Elijah Talamas and Alexander Timokhov. Voucher adult specimens of parasitoids are deposited in the collection of the Department of Entomology of Moscow State University (Moscow, Russia), and in the Florida State Collection of Arthropods (Gainesville, Florida, USA).

Preparation of chromosomes

Chromosome preparations were made from cerebral ganglia of parasitoid prepupae using a modified version of the technique described by Imai et al. [1988]. Wasps were dissected in $0.5 \%$ hypotonic sodium citrate solution containing $0.005 \%$ colchicine, and the tissues were incubated in fresh solution for 30 minutes at room

Table 2. Relative lengths of chromosomes of three species of the genus Trissolcus (mean $\pm \mathrm{SD}$ ).

Таблица 2. Относительная длина хромосом трёх видов рода Trissolcus (среднее значение \pm стандартное отклонение).

\begin{tabular}{|c|c|c|c|}
\hline $\begin{array}{c}\text { Chromo- } \\
\text { some no. }\end{array}$ & T. kozlovi & T. rufiventris & T. semistriatus \\
\hline 1 & $15.96 \pm 0.52$ & $16.04 \pm 0.95$ & $14.49 \pm 0.79$ \\
\hline 2 & $12.07 \pm 0.02$ & $14.40 \pm 1.43$ & $12.39 \pm 1.02$ \\
\hline 3 & $10.56 \pm 0.07$ & $12.44 \pm 0.71$ & $11.03 \pm 0.58$ \\
\hline 4 & $10.22 \pm 0.26$ & $11.43 \pm 0.16$ & $10.43 \pm 0.36$ \\
\hline 5 & $9.70 \pm 0.18$ & $10.20 \pm 0.81$ & $9.93 \pm 0.44$ \\
\hline 6 & $9.49 \pm 0.03$ & $8.84 \pm 0.80$ & $9.31 \pm 0.41$ \\
\hline 7 & $9.27 \pm 0.03$ & $7.82 \pm 0.06$ & $8.77 \pm 0.17$ \\
\hline 8 & $8.90 \pm 0.45$ & $6.79 \pm 0.40$ & $8.41 \pm 0.22$ \\
\hline 9 & $7.68 \pm 0.25$ & $6.32 \pm 0.57$ & $8.02 \pm 0.29$ \\
\hline 10 & $6.15 \pm 0.34$ & $5.72 \pm 0.93$ & $7.22 \pm 0.46$ \\
\hline
\end{tabular}

temperature. The material was transferred to a precleaned microscope slide using a Pasteur pipette and gently flushed with Fixative I (glacial acetic acid: absolute ethanol: distilled water $3: 3: 4)$. Tissues were disrupted in an additional drop of Fixative I using dissecting needles. Another drop of Fixative II (glacial acetic acid: absolute ethanol 1:1) was then applied to the center of the area and blotted off the edges of the slide. The slide was air dried at room temperature. Preparations were stained with freshly prepared 3\% Giemsa solution in $0.05 \mathrm{M}$ Sorensen's phosphate buffer $\left(\mathrm{Na}_{2} \mathrm{HPO}_{4}+\mathrm{KH}_{2} \mathrm{PO}_{4}, \mathrm{pH} 6.8\right)$.

Image acquisition and analysis

Mitotic divisions were studied and photographed using an optic microscope Zeiss Axioskop 40 FL fitted with a digital camera AxioCam MRc (Carl Zeiss, Oberkochen, Germany) (Table 1). To obtain karyograms, the resulting images were processed with image analysis programs Zeiss AxioVision version 3.1 and Adobe Photoshop version 8.0. Chromosomes from selected diploid metaphase plates were measured using KaryoType software version 2.0 (Table 2). Since centromere positions could not be reliably identified for many chromosomes, only average values of relative lengths of chromosomes (RLs) are given in the present paper. Nevertheless, certain chromosomes were classified using results from selected metaphase plates.

\section{Results and discussion}

Trissolcus kozlovi (Fig. 1). $2 \mathrm{n}=20$. Chromosomes more or less gradually decrease in size, but the first pair is obviously longer than the remaining elements (Table $2)$. At least some chromosomes are clearly bi-armed.

T. rufiventris (Fig. 2). $\mathrm{n}=10$ and $2 \mathrm{n}=20$. In this species, as in the previous one, chromosomes can be arranged in a more or less continuously decreasing order of size. The first and second chromosome pairs are slightly longer than the remaining elements. As in T. kozlovi, at least some chromosomes are obviously biarmed. 


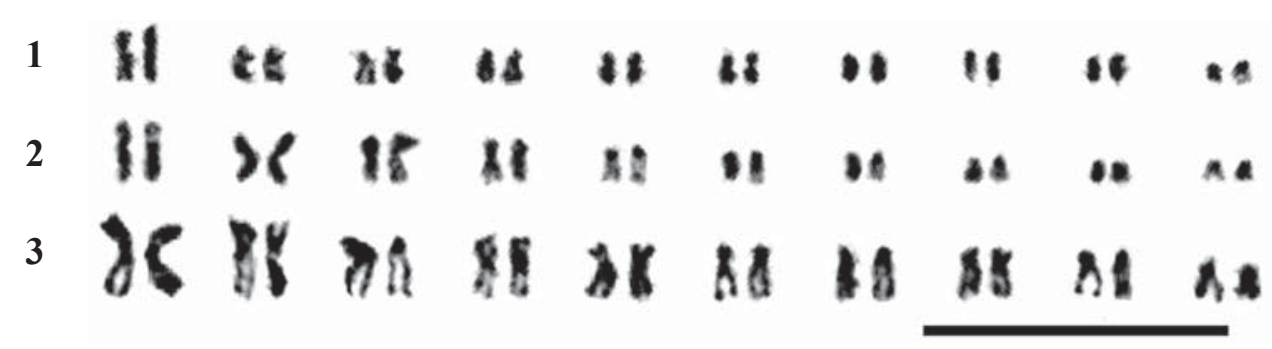

Figs 1-3. Diploid karyograms of Trissolcus species: $1-$ T. kozlovi, $2-$ T. rufiventris, $3-$ T. semistriatus. Bar $=10 \mu \mathrm{m}$. Рис. 1-3. Диплоидные кариограммы видов Trissolcus: 1 - T. kozlovi, 2 - T. rufiventris, 3 - T. semistriatus. Масштаб $10 \mu$ m.

T. semistriatus (Fig. 3). $2 \mathrm{n}=20$. As in the two previous species, chromosomes more or less gradually decrease in size. The first chromosome pair is slightly longer than the remaining elements. Again, at least some chromosomes (e.g. those of the first two pairs) are clearly bi-armed. No karyotypic variation was detected between specimens of $T$. semistriatus having different geographic origin.

Previously, Dreyfus \& Breuer [1944], Gokhman [2009] and Fusu et al. [2013] examined chromosome sets of three species of Scelionidae of the subfamily Telenominae, i.e. Telenomus fariai Costa Lima, 1927, T. turesis Walker, 1836 [= T. chloropus (Thomson, 1861)] and Trissolcus basalis (Wollaston, 1858) respectively. Nevertheless, our paper represents the first comparative karyotypic study of the genus Trissolcus. Nowadays, chromosomes of only four members of the genus Trissolcus - T. basalis, T. kozlovi, T. rufiventris and T. semistriatus, are known (see Fusu et al. [2013]). Although all these species have the same chromosome number, $2 n=20$, they belong to different species groups [Talamas et al., 2017]. Specifically, T. kozlovi is included into the flavipes group, while the three other species represent the basalis group. Our study demonstrates that all studied members of Trissolcus differ in some details of their karyotype structure as well (see Table 2). For example, T. basalis is perhaps the closest to the hypothetical ancestor of the Cynipoidea + Proctotrupoidea s.l. + Chalcidoidea clade in terms of its karyotype structure [Gokhman, 2011]. The ancestral haploid chromosome set is supposed to contain eleven acrocentrics (or subtelocentrics), and the karyotype similar to that of $T$. basalis could therefore originate via central chromosomal fusion (see Gokhman [2009]). On the other hand, the karyotype of $T$. kozlovi resembles that of T. basalis by having the first chromosome pair substantially longer than the remaining elements. However, this feature is an apparent symplesiomorphy of the two species, and subsequent rearrangements could alter the karyotype structure of the other members of the genus.
Acknowledgements. The authors are grateful to Elijah Talamas (Florida State Collection of Arthropods) for identifying specimens of Scelionidae. The present work is partly supported by a research grant from the Russian Foundation for Basic Research no. 18-04-00611.

\section{References}

Bebber D.P., Polaszek A., Wood J.R.I., Barker C., Scotland R.W 2014. Taxonomic capacity and author inflation // New Phytologist. Vol.202. P.741-742. doi: 10.1111/nph.12745.

Dreyfus A., Breuer M.E. 1944. Chromosomes and sex determination in the parasitic hymenopteron Telenomus fariai (Lima) // Genetics. Vol.29. P.75-82.

Forbes A.A., Bagley R.K., Beer M.A., Hippee A.C., Widmayer H.A. 2018. Quantifying the unquantifiable: Why Hymenoptera, not Coleoptera, is the most speciose animal order // BMC Ecology. Vol.18. Paper 21. doi: 10.1186/s12898-018-0176-x.

Fusu L., Bin F., Popovici O.A. 2013. First report of chromosomes of the parasitoid wasp Trissolcus basalis (Wollaston) (Hymenoptera: Platygastridae: Telenominae)// Entomological Science. Vol.16. P.263-265. doi: 10.1111/ens.12011.

Godfray H.C.J. 1994. Parasitoids: behavioral and evolutionary ecology. Princeton: Princeton University Press. XI +475 p.

Gokhman V.E. 2009. Karyotypes of parasitic Hymenoptera. Dordrecht: Springer. XIII + 183 p. doi: 10.1007/978-1-4020-9807-9.

Gokhman V.E. 2011. Morphotypes of chromosome sets and pathways of karyotype evolution of parasitic Hymenoptera // Russian Entomological Journal. Vol.20. No.3. P.265-271.

Imai H.T., Taylor R.W., Crosland M.W.J., Crozier R.H. 1988. Modes of spontaneous chromosomal mutation and karyotype evolution in ants with reference to the minimum interaction hypothesis // Japanese Journal of Genetics. Vol.63. P.159-185. doi: $10.1266 /$ jjg.63.159.

Platygastroidea. 2019. Database available at Hymenoptera Online (https://hol.osu.edu/index.html?id=195000) (accessed 10 February 2019).

Popovici O.A., Vilhelmsen L., Masner L., Mikó I., Johnson N. 2017. Maxillolabial complex in scelionids (Hymenoptera: Platygastroidea): morphology and phylogenetic implications // Insect Systematics and Evolution. Vol.48. No.4. P.315-439. doi: 10.1163/1876312x-48022156.

Quicke D.L.J. 1997. Parasitic wasps. London: Chapman \& Hall. XVII $+470 \mathrm{p}$.

Talamas E.J., Buffington M.L., Hoelmer K. 2017. Revision of Palearctic Trissolcus Ashmead (Hymenoptera, Scelionidae) // Journal of Hymenoptera Research. Vol.56. P.3-185. doi: 10.3897/ jhr. 56.10158 